\title{
Climatic changes and the fate of mountain herbivores
}

\author{
Sandro Lovari ${ }^{1,2}$ (ID - Sara Franceschi ${ }^{3}$ (D) - Gianpasquale Chiatante ${ }^{4}$. \\ Lorenzo Fattorini ${ }^{3}$. Niccolò Fattorini ${ }^{1}$ (D) . Francesco Ferretti ${ }^{1}$ (D)
}

Received: 23 April 2019 / Accepted: 15 July 2020/ Published online: 12 August 2020

(C) The Author(s) 2020

\begin{abstract}
Mountains are strongly seasonal habitats, which require special adaptations in wildlife species living on them. Population dynamics of mountain ungulates are largely determined by the availability of rich food resources to sustain lactation and weaning during summer. Increases of temperature affect plant phenology and nutritional quality. Cold-adapted plants occurring at lower elevations will shift to higher ones, if available. We predicted what could happen to populations of mountain ungulates based on how climate change could alter the distribution pattern and quality of highelevation vegetation, using the "clover community-Apennine chamois Rupicapra pyrenaica ornata" system. From 1970 to 2014, increasing spring temperatures $\left(2{ }^{\circ} \mathrm{C}\right)$ in our study area led to an earlier (25 days) onset of green-up in Alpine grasslands between 1700 and $2000 \mathrm{~m}$, but not higher up. For 1970-2070, we have projected trends of juvenile winter survival of chamois, by simulating trajectories of spring temperatures and occurrence of clover, through models depicting four different scenarios. All scenarios have suggested a decline of Apennine chamois in its historical core range, during the next 50 years, from about $28 \%$ to near-extinction at about $95 \%$. The negative consequences of climate changes presently occurring at lower elevations will shift to higher ones in the future. Their effects will vary with the species-specific ecological and behavioural flexibility of mountain ungulates, as well as with availability of climate refugia. However, global shifts in distributional ranges and local decreases or extinctions should be expected, calling for farsighted measures of adaptive management of mountain-dwelling herbivores.
\end{abstract}

Keywords Climate change Extinction risk $\cdot$ Mountain herbivores $\cdot$ Population modelling · Rupicapra $\cdot$ Temperature increase

Electronic supplementary material The online version of this article (https://doi.org/10.1007/s10584-02002801-7) contains supplementary material, which is available to authorized users.

Sandro Lovari

sandro.lovari@gmail.com

Extended author information available on the last page of the article 


\section{Introduction}

Climate changes are not a new event; for example, over 50 climate changes occurred during the Pleistocene and the Holocene (Lourens 2004; Wanner et al. 2015), with most of them lasting a minimum of several hundred years (Crawford 2014). Many species of plants and animals survived either by adapting to the new local conditions or by moving to refuge areas (climate refugia: Dobrowski 2011; Gavin et al. 2014; Morelli et al. 2016, for reviews), where they could tolerate the local environmental conditions and from which they later recolonised their earlier range, when climate conditions turned again suitable (Hewitt 1996; Lorenzini and Lovari 2006; Crawford 2014; Li et al. 2016). Organisms which neither adapted nor moved to refugia went extinct. Species living in extreme conditions, e.g. in Polar regions and deserts, may find it particularly difficult to quickly change their adaptations developed over millions of years or to find suitable refuge areas (Parmesan 2006, for a review). In addition, changes in distribution of other species with wider ecological tolerance may further contribute to the decline of highly specialised species through competition (Hersteinsson and Macdonald 1992; Lovari et al. 2013; Stenseth et al. 2015; Ferretti et al. 2018).

Species adapted to high-elevation habitats are also particularly sensitive to climatic changes, in some cases leading to local extinctions (Nogués-Bravo et al. 2007; Parmesan 2006). Cold-adapted plant associations on mountains have shifted to higher elevations because of warmer conditions (Lenoir et al. 2008; Gottfried et al. 2012; Pauli et al. 2012; Telwala et al. 2013). Presumably, herbivores feeding on them will also tend to follow the vegetation shift, although evidence is still scanty (Büntgen et al. 2017). In the warm months, access to highquality forage is crucial for reproductive success of mountain ungulates, as juvenile growth, which then affects winter survival, is strongly dependent on summer food availability and quality (Festa-Bianchet 1988; Festa-Bianchet and Jorgenson 1998; Coté and Festa-Bianchet 2001; Scornavacca et al. 2016). Mountain ungulates are not a taxonomic group, although the large majority of them (75\%; $n=41$ species; Table S1, Supplementary Material 1) belongs to the subfamily Caprinae (Bovidae) and nearly all of them $(92 \%)$ inhabit the Holarctic bioregion (Shackleton 1997). They show adaptations to climb and use rocky or rugged ground for escape terrain, differently from other ungulates which may also occur at high elevations (Schröder 1985). Mountain ungulates present special conservation problems: $70 \%(n=41$ species; Table S1, Supplementary Material 1) are in the Near-Threatened or in the Threatened IUCN risk categories and could be further imperilled by the ongoing climate change. Refuge areas are more likely to be available on mountains with a greater elevational gradient (Șekercioğlu et al. 2012), which should provide a wider opportunity for vegetation shifts and herbivore movements compared to mountains with a limited elevational range. Physiographic factors shaping topoclimatic effects also determine the occurrence of microrefugia, particularly on mountains (Dobrowski 2011). Although availability of refuge areas varies with mountain topography (Elsen and Tingley 2015), about 50\% of mountain groups in the Holarctic bioregion-where the large majority of mountain ungulates dwells - shows a decrease of refuge areas with increasing elevation (Elsen and Tingley 2015). Therefore, especially in this bioregion, coldadapted vegetation on mountains with a limited elevational range $(<2000 \mathrm{~m})$ is expected to show earlier the effects of the temperature increase because of snowmelt, in respect to vegetation of mountains with higher elevations (cf. Martin et al. 1994; Beniston 1997; Beniston et al. 2018; Rogora et al. 2018), thus allowing predictions on the evolution of Alpine ecosystems with time. 
Climate change patterns may vary between geographical regions in terms of snow and rain (Parmesan and Matthews 2006), with a global increase of temperatures (Hegerl et al. 2018), sometimes even having locally contrasting effects on population dynamics of mountain ungulates (Loison et al. 1999), thus making it difficult to predict a general pattern. In spite of local variations, it has been suggested that warmer weather during the vegetative season may have particularly negative effects on body mass (Rughetti and Festa-Bianchet 2012; Mason et al. 2014a), fecundity of females (Corlatti et al. 2018) and offspring survival (Douhard et al. 2018; Ferretti et al. 2018), affecting population dynamics of mountain herbivores.

The chamois Rupicapra spp. (Bovidae: Caprinae) is an abundant ungulate found in the main mountain groups of Europe and the Near East (c. 500,000 adult individuals; iucnredlist. org, accessed on 24.06.2020). It shows a number of physical, behavioural and ecological adaptations to life on mountains (Corlatti et al. in press). The Apennine chamois $R$. pyrenaica ornata lives on the Apennines, a mountain chain crossing the Italian Peninsula longitudinally. In the Apennines, most mountain tops range between 1500 and $2000 \mathrm{~m}$ a.s.l., with the highest summit (Corno Grande, $2912 \mathrm{~m}$ ) in the Gran Sasso Massif, Central Apennines. Up to the Holocene, chamois occurred all over the Apennine range and neighbour areas, but at the end of the ice age, they retreated to some mountain tops of the Central and Southern Apennines (Masini and Lovari 1988). Ferrari et al. (1988) showed that, while male Apennine chamois are more catholic in diet, females and juveniles concentrate their summer food habits on several plant communities, especially the glacial relict grassland with clover Trifolium thalii which supplies a particularly protein-rich and fibre-poor diet. This forb is rare and extra-zonal in the Northern and Central Apennines, whereas it is common in the Alpine vegetation belt of the Alps (Pignatti 1982). It grows on slightly acidic soils, in shallow dolines with long-lasting snow cover (Ferrari et al. 1988; Ferrari and Rossi 1995), thus being particularly sensitive to temperature increases, e.g. because of climatic variations, and can be used as a proxy to assess temperature-driven vegetation changes.

As population dynamics of mountain ungulates is strongly dependent on food resources, one could expect that a dramatic change in availability and quality of vegetation, e.g. driven by an increase of temperature, has negative effects on the survival of mountain ungulates (e.g. Douhard et al. 2018; Ferretti et al. 2018, see also above). The system formed by the plant community with $T$. thalii and the Apennine chamois can be used as a case study of what could happen to populations of mountain ungulates when climatic changes alter the distribution pattern and quality of cold-adapted vegetation (Lenoir et al. 2008; Gottfried et al. 2012; Pauli et al. 2012; Telwala et al. 2013). Our work aims to predict the population dynamics of mountain ungulates when local key-food resources are altered because of an increase of temperature.

\section{Materials and methods}

\subsection{Study area and population}

Our study was conducted in the Abruzzo, Lazio and Molise National Park (ALMNP), in the Central Apennines (Italy; latitude: $42^{\circ} 00^{\prime} 37^{\prime \prime}$ to $41^{\circ} 35^{\prime} 25^{\prime \prime} \mathrm{N}$, longitude: $13^{\circ} 29^{\prime} 17^{\prime \prime}$ to $14^{\circ} 02^{\prime}$

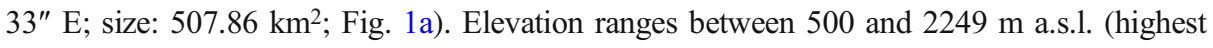
peak: Mt. Meta), with most of the area lying between 1100 and $1900 \mathrm{~m}$ (Primi et al. 2016). 


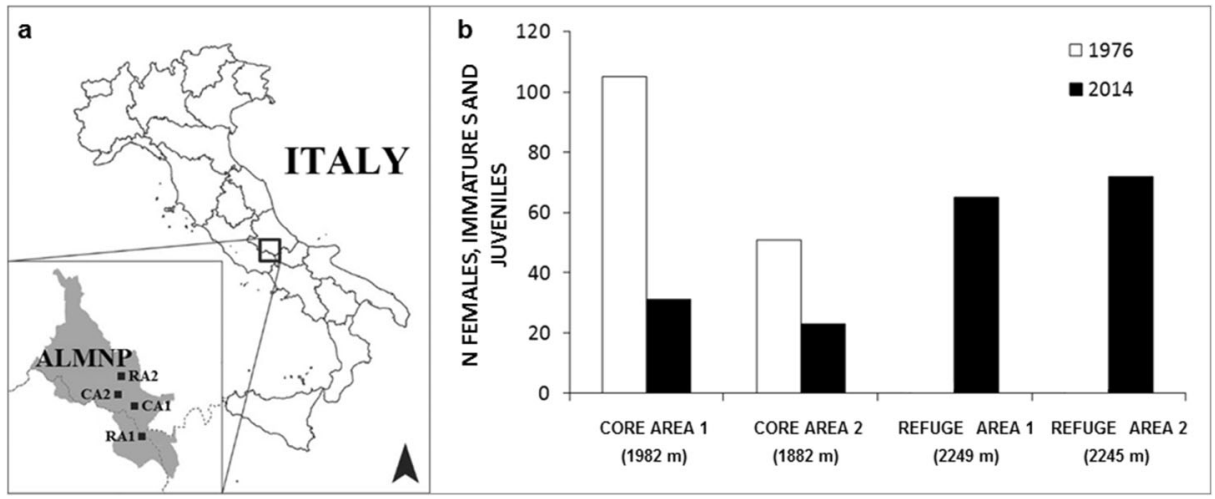

Fig. 1 a Location of the Abruzzo, Lazio and Molise National Park (ALMNP) and b changes in minimum numbers of female, immature and offspring chamois, recorded in 1976 (Perco et al. 1976) and 2014 (Latini and Asprea 2014), in historical core areas (CAs) and in recently colonised ones, i.e. refuge areas (RAs)

There is no dry season, and snow cover lasts from mid-November until mid/late spring, depending on the elevation. The vegetation changes according to elevational belt (Primi et al. 2016). Natural timberline occurs at less than $1900 \mathrm{~m}$ (Ravazzi and Aceti 2004). Below the tree line, vegetation includes forests dominated by beech Fagus sylvatica and secondary grasslands. The subalpine belt occurs above the tree line $(>1700 \mathrm{~m})$ and includes natural $/ \mathrm{semi}$ natural grasslands (hereafter, "Alpine grasslands", c. $10 \%$ of land cover) and screes with sparse vegetation; snow cover lasts until early June. Most of the Alpine grasslands (c. 92\%) lie between 1700 and $2000 \mathrm{~m}$, while only a smaller proportion (c. 8\%) lies above $2000 \mathrm{~m}$ (see Sect. 2.3, below).

The ALMNP includes the historical range of the Apennine chamois, which survived only in two sites of this area (Lovari 1977). Since the early 1990s, it has been translocated for conservation purposes to other protected areas of the Central Apennines, with a current total population of less than 2500 individuals (Corlatti et al. in press). Even in ALMNP, Apennine chamois went nearly extinct during World War II, because of increased poaching (Lovari 1985). Its numbers slowly recovered and, between 1970 and 1990, oscillated at c. 300 individuals, which have nearly doubled after the Park boundaries were extended to include the Mainarde chain (1990-present; Lovari 1985; Duprè et al. 2001; Mari and Lovari 2006; Asprea 2016). During the last few decades, numbers of chamois have decreased in historical core areas of ALMNP (c. 70\% decrease in core area 1: upper Val Di Rose/Mt. Boccanera; $c$. 50\% decrease in core area 2: Mt. Amaro; Fig. 1b; cf. Perco et al. 1976 with Latini and Asprea 2014), because of heavy winter mortality of juveniles, related to a lower availability of appropriate food resources (Lovari et al. 2014; Ferretti et al. 2015; Corazza et al. 2016; Scornavacca et al. 2016; Ferretti et al. 2018). Conversely, an increase in the population of chamois was recorded in two new areas both above $2000 \mathrm{~m}$ a.s.l. (refuge area 1: Mt. Meta; refuge area 2: Mt. Marsicano; Fig. 1b; Latini and Asprea 2014), where a maximum of only five or six males were present in 1975s-1980s, with no mixed group of females, yearlings and juveniles (S.L., unpublished; Perco et al. 1976).

In ALMNP, previous studies have shown that chamois account for a negligible proportion of the diet of the grey wolf Canis lupus (<2\%; Patalano and Lovari 1993; Ciucci et al. 2020) and the Apennine brown bear Ursus arctos marsicanus (0.05\%; Ciucci et al. 2014), with the former relying especially on abundant populations of other ungulate species. Stable to growing 
populations of red deer Cervus elaphus (Latini et al. 2015a), roe deer Capreolus capreolus (Latini et al. 2015a) and wild boar Sus scrofa (Fabbri et al. 1983; S.L., N.F., F.F., own observations) occur in ALMNP. The golden eagle may prey mainly on juvenile chamois, although chamois antipredator defence usually does not allow it (Scornavacca and Brunetti 2015).

\subsection{Meteorological data}

We obtained temperature data of the study area at the terrain level from the NCEP/NCAR reanalysis project (NOAA/OAR/ESRL PSD, Boulder, CO, USA; Kalnay et al. 1996) using the specific R package 'RNCEP' (Kemp et al. 2012). These data have been customarily used in climatological and ecological research (Kaskaoutis et al. 2014; Panuccio et al. 2016). They cover the variation of atmospheric variables from 1957 to present. These data have a spatial resolution of $2.5^{\circ} \times 2.5^{\circ}$ and a temporal resolution of $6 \mathrm{~h}(00: 00,06: 00,12: 00,18: 00 \mathrm{~h} \mathrm{UTC})$ (Kemp et al. 2012). We used daily temperature data taken from 1970 to 2014 at 12:00 (solar time).

\subsection{Vegetation productivity data}

We analysed vegetation activity through the Enhanced Vegetation Index (EVI; Huete et al. 2002), a satellite-derived index that identifies the photosynthetically active signal of vegetation. This index is based on light absorption by chlorophyll in the red wavelength of the optical spectrum, while mesophyll scatters light in the near infrared. Because EVI is correlated positively with vegetation productivity (Running et al. 2004), this index may be used to assess the timing of phenological changes of vegetation in grasslands (Ballesteros et al. 2013; Villamuelas et al. 2016). Furthermore, the EVI has been shown to be a proxy reflecting the diet quality of our study species, in spring (Villamuelas et al. 2016). EVI is less sensitive than NDVI (Normalized Difference Vegetation Index) to the influence of atmospheric aerosol, which improves its sensitivity to vegetation signals (Huete et al. 2002).

We obtained EVI data from the MOD13Q1 product of the MODIS sensor (Moderate Resolution Imaging Spectroradiometer) from the TERRA satellite of NASA (Huete et al. 2002; Justice et al. 2002) accessible from the Earth Explorer website of the United States Geological Survey (USGS; https://earthexplorer.usgs.gov, accessed on 1 Aug 2016). We used 342 scenes of MODIS from 2000 to 2014, with a temporal time resolution of 16 days and a spatial resolution of $250 \mathrm{~m}$.

Only data for Alpine grasslands were considered. First, we superimposed a grid with cells of $200 \times 200 \mathrm{~m}$ to the study area and we classified as 'grassland' the cells containing at least $70 \%$ of grasslands based on the 4th level Corine Land Cover map of the study area. Further, we selected only the cells located at more than $1700 \mathrm{~m}$ of elevation, based on the digital elevation model with a spatial resolution of $25 \mathrm{~m}$ (Alpine grasslands; $5196 \mathrm{ha}$ ). Finally, we separated the Alpine grasslands in 'lower elevation' (1700-2000 m; $47.76 \mathrm{~km}^{2}$ ) and 'higher elevation' ( $>2000 \mathrm{~m} ; 4.2 \mathrm{~km}^{2}$ ) ones, to assess potential differences in vegetation dynamics. EVI data are available only from 2000 onwards. For 1970-1999, we estimated EVI by modelling the relationships between the available EVI values (2000-2014) and meteorological data (see Supplementary Material 1). We determined three EVI metrics to explore vegetation phenology through the estimated (1970-1999) or obtained (2000-2014) EVI values: (i) the onset of green-up, (ii) the integrated EVI (iEVI) of April and (iii) the duration of the greenness 
plateau (Fig. S1, Supplementary Material 1). The onset of green-up is the beginning of the growing season and was defined as the time when the maximum increase of EVI between two consecutive dates occurred (Pettorelli et al. 2005, 2007; Garel et al. 2011). We used the integrated EVI of April because it correlates with vegetation biomass (Pettorelli et al. 2005) and was calculated as the sum of positive EVI values of April (Pettorelli et al. 2005; Pettorelli et al. 2007; Hamel et al. 2009; Garel et al. 2011). We chose April because in this month, there was the maximum rate of increase in plant productivity during green-up, in our study area. The duration of the greenness plateau corresponds to the period of high photosynthetic activity (Pettorelli et al. 2005) and was calculated as the difference between the time when the EVI started to decrease and the time when the EVI plateau began.

\subsection{Clover vegetation and chamois numbers}

We used data from Rossi (1985), in 1980s, and Lovari et al. (2014), in 2010s, in the core area of chamois (upper Val di Rose and surroundings), to analyse the frequency of occurrence of clover $T$. thalii, as a proxy of cold-adapted vegetation particularly sensitive to temperature variations. Rossi (1985) and Lovari et al. (2014) estimated visually presence/absence of clover through vegetation surveys in circular plots, using the phytosociological method (BraunBlanquet 1964). In the same area, we estimated the mortality of chamois juveniles over winter by the ratio between yearlings counted in year $t$ and the number of juveniles counted in year $t-1$ (hereafter, yearling /juvenile $_{t-1}$ ratio), through personal observations (1980s: S.L., unpublished; Rossi 1985; 2010s: Lovari et al. 2014; Ferretti et al. 2015; Scornavacca et al. 2016; Ferretti et al. 2018). For this purpose, we used the maximum number of individuals belonging to each age class observed daily in summer, each year (range: $c$. 89-120 h of observation per year; Rossi 1985; S.L. unpublished; Lovari et al. 2014; Ferretti et al. 2015; Scornavacca et al. 2016; Ferretti et al. 2018). In each observation day, 2-3 trained observers searched actively for each herd, which should provide reliable information on age, structure and numbers of the local herds. In fact, groups of females, kids and yearlings of Apennine chamois use open habitats from mid-June to November (Lovari and Cosentino 1986) and show a marked site fidelity (data based on GPS/VHF radio-tracking: Latini et al. 2013). In addition, some yearlings appear to depart from the maternal group mainly from the autumn (Fattorini et al. 2019).

\subsection{Analysis of changes in temperature and vegetation productivity}

We ran linear regressions on the time series of both the temperature and the EVI metrics (Zuur et al. 2007) to assess the temporal variation of climate and vegetation phenology in the Alpine grasslands of the ALMNP, between 1970 and 2014. We tested the significance of the regression slope by one-way ANOVA (Wang and Carter 1983). We checked normality and temporal autocorrelation of residuals with the Kolmogorov-Smirnov test (Legendre and Legendre 1998) and the autocorrelation function plot (Cowpertwait and Metcalfe 2009), respectively. All models showed normally distributed and temporally uncorrelated residuals (Table S8, Fig. S2 and Fig. S3, Supplementary Material 1).

\subsection{Simulation of trajectories of spring temperatures}

Of all seasons and variables we considered, only spring temperatures showed a statistically significant increase over the last decades (Table S9; Fig. S4, Supplementary Material 1). Thus, 
we considered mean spring temperatures $(x)$ from 1970 to 2014 to predict trajectories for the next 56 years, up to 2070 . Since the early twentieth century, there have been linear/exponential increases of temperatures (Hegerl et al. 2018: 3); therefore, we have assumed no major variation of the trend of temperatures in the next few decades, up to 2070. From 2015 to 2070, 10,000 trajectories of mean spring temperatures were simulated according to the following linear model

$$
x_{t i}=\alpha+\beta t+\varepsilon_{t i}, i=1, \ldots, 10000, t=2015, \ldots, 2070
$$

where $x_{t i}$ denotes the mean spring temperature of the $i$-th trajectory for the year $t$ and $\alpha$ and $\beta$ were the OLS estimates obtained from mean spring temperatures for the period 1970-2014 (Table S10, Supplementary Material 1), while $\varepsilon_{t i}$ was the error term assumed to be a normal random variable with expected average 0 and variance $\sigma^{2}$ estimated by the residual variance of the OLS regression (Table S10, Supplementary Material 1). As OLS regression of mean spring temperatures during 1970-2014 did not show autocorrelated residuals (Durbin-Watson test; $p=0.124$ ), we did not assume them in our simulations.

The temperature change we predicted up to 2070 is consistent with that projected in our study area through the ensemble of 44 CMIP5 scenarios based on 11 Global Circulation Models coupled with four Representative Concentration Pathways reflecting the possible range of future radiative forcing (see Supplementary Material 2).

\subsection{Simulation of trajectories of proportion of plots containing clover}

We ran our simulations according to four different scenarios relating proportion of plots containing clover $(c)$ to mean spring temperatures, with $0 \leq c \leq 100$. We considered different types of relationships to reach widely reliable predictions, as temperature is the ultimate driver of quantity of growing clover T. thalii (Ferrari and Rossi 1995). The first scenario (A) assumed a linear relationship between proportion of plots with clover at year $t$ and mean spring temperature at the same year, the second (B) and the third (C) scenarios assumed a power relationship with negative and positive exponent, respectively, whereas the fourth (D) assumed a sigmoidal relationship (Fig. S5, Supplementary Material 1). From any trajectory of both observed and simulated temperatures, the corresponding trajectory of proportions of plots containing clover vegetation for the period 1970-2070 was generated, depending on which scenario, by the following four models:

$$
\begin{array}{lr}
c_{t i}=\alpha+\beta x_{t i}+\varepsilon_{t i}, i=1, \ldots, 10000, t=1970, \ldots, 2070 & \text { scenario A } \\
c_{t i}=\alpha+\beta x_{t i}^{-\gamma}+\varepsilon_{t i}, i=1, \ldots, 10000, t=1970, \ldots, 2070, \gamma>0 & \text { scenario B } \\
c_{t i}=\alpha+\beta x_{t i}^{\gamma}+\varepsilon_{t i}, i=1, \ldots, 10000, t=1970, \ldots, 2070, \gamma>0 & \text { scenario C } \\
c_{t i}=100-\frac{100}{1-\left(\frac{x_{i i}}{\beta}\right)^{\gamma}}+\varepsilon_{t i}, i=1, \ldots, 10000, t=1970, \ldots, 2070 & \text { scenario D }
\end{array}
$$

where $c_{t i}$ denoted the proportion of plots containing clover in the $i$-th trajectory for the year $t$; the parameters $\alpha, \beta$, and $\gamma$ were determined in such the way that regression curves passed through the observed values (Table S11, Supplementary Material 1); as customary when modelling rates, proportions or percentage, $\varepsilon_{i t}$ was an error term generated from a beta distribution (e.g. Johnson and Kotz 1970) in the range $-A_{i t}, A_{i t}$, with $A_{i t}=\min \left\{c_{t i}, 100-c_{t i}\right\}$ to have low error term variances at the bounds of the percentage values (i.e. 0 and 100) and have shape parameters $a=b=4$.

For an alternative explanation of data in the range $0-100$, we have also fitted these data through beta regression models (Ferrari and Cribari-Neto 2004), assuming the four 
relationships (A, B, C, D) between the logit of $c$ and the mean spring temperature (see Supplementary Material 3). However, beta regression strongly depended from the precision parameter and the trends were quite similar to those obtained under the assumption of a direct relationship between $c$ and the mean spring temperature (see Supplementary Material 3). By contrast, as similar results were achieved even for $a=b=20$, our results assuming a direct relationship were stable with respect to the shape parameters $a$ and $b$.

\subsection{Simulation of trajectories of chamois yearling / $_{\text {juvenile }}$ t-1 ratio}

Ferretti et al. (2018) showed that juvenile winter survival of chamois can be negatively influenced by hot-dry weather conditions during spring-summer, through depletion of keyfood resources. Our simulations assumed a correlation between juvenile chamois yearling $t$ juvenile $_{t-1}$ ratio $(s)$ and proportion of plots containing clover, where $0 \leq s \leq 1$ (Table S12, Supplementary Material 1). For each scenario and for each trajectory of simulated proportions of plots containing clover, the corresponding trajectory of chamois yearling $\mathrm{f}_{t}$ juvenile $_{t-1}$ ratio for the period 1970-2070 was generated according to the following linear model

$$
s_{t i}=\alpha+\beta c_{t i}+\varepsilon_{t i}, i=1, \ldots, 10000, t=1970, \ldots, 2070
$$

where $s_{t i}$ denoted the yearling $/$ juvenile t-1 ratio in the $i$-th trajectory for the year $t$, and $\alpha$ and $\beta$ were the OLS estimates obtained from the observed proportions of plot containing clover and yearling $t$ juvenile $_{t-1}$ ratio in the period 1970-2014 (Table S12, Supplementary Material 1). As for the simulations of proportion of plots containing clover, $\varepsilon_{t i}$ was the error term assumed to be a beta random variable in the range $-A_{i t}, A_{i t}$, with $A_{i t}=\min \left\{c_{t i}, 1-c_{t i}\right\}$ to have low error term variances at the bounds of the yearling /juvenile $_{t-1}$ ratio (i.e. 0 and 1) and have shape parameters $a=b=4$.

\section{Results}

\subsection{Changes in temperature and vegetation productivity}

Between 1970 and 2014, temperatures increased in spring by c. $2{ }^{\circ} \mathrm{C}$, but they did not increase in other seasons (Table S9; Fig. S4, Supplementary Material 1). An earlier (c. 25 days) onset of green-up in the Alpine grasslands has been found between 1700 and $2000 \mathrm{~m}\left(\beta=-0.484 \pm 0.194 ; F_{1,44}=\right.$ $6.217, p=0.016, R^{2}=0.124$; Fig. $\left.2 \mathrm{a}\right)$, but not higher up $\left(\beta=-0.124 \pm 0.106 ; F_{1,44}=1.356, p=\right.$ $0.251, R^{2}=0.124$; Fig. $2 \mathrm{~b}$ ). The maximum rate of growth in early spring increased through time, at both the lower and higher elevations $\left(\beta=0.002 \pm 0.001 ; F_{1,44}=8.272, p=0.006, R^{2}=0.158\right.$, Fig. $2 \mathrm{c}$; $\beta=0.001 \pm 0.0003 ; F_{1,44}=5.109, p=0.029, R^{2}=0.104$, Fig. $\left.2 \mathrm{~d}\right)$. Over the years, the duration of the greenness plateau did not change at the lower elevations $\left(\beta=-0.017 \pm 0.014 ; F_{1,44}=1.520, p=\right.$ $0.224, R^{2}=0.033$; Fig. $\left.2 \mathrm{e}\right)$, but decreased at the higher ones $\left(\beta=-0.037 \pm 0.014 ; F_{1,44}=6.888, p=\right.$ $0.012, R^{2}=0.135$; Fig. 2f).

\subsection{Changes in chamois population dynamics}

Trends of yearling $f_{t}$ juvenile $_{t-1}$ ratio from 2015 until 2070 were obtained by simulating trajectories of mean spring temperatures (Fig. 3) and proportions of plots with clover (Fig. S6, Supplementary Material 1), through models depicting four different scenarios (see Methods 

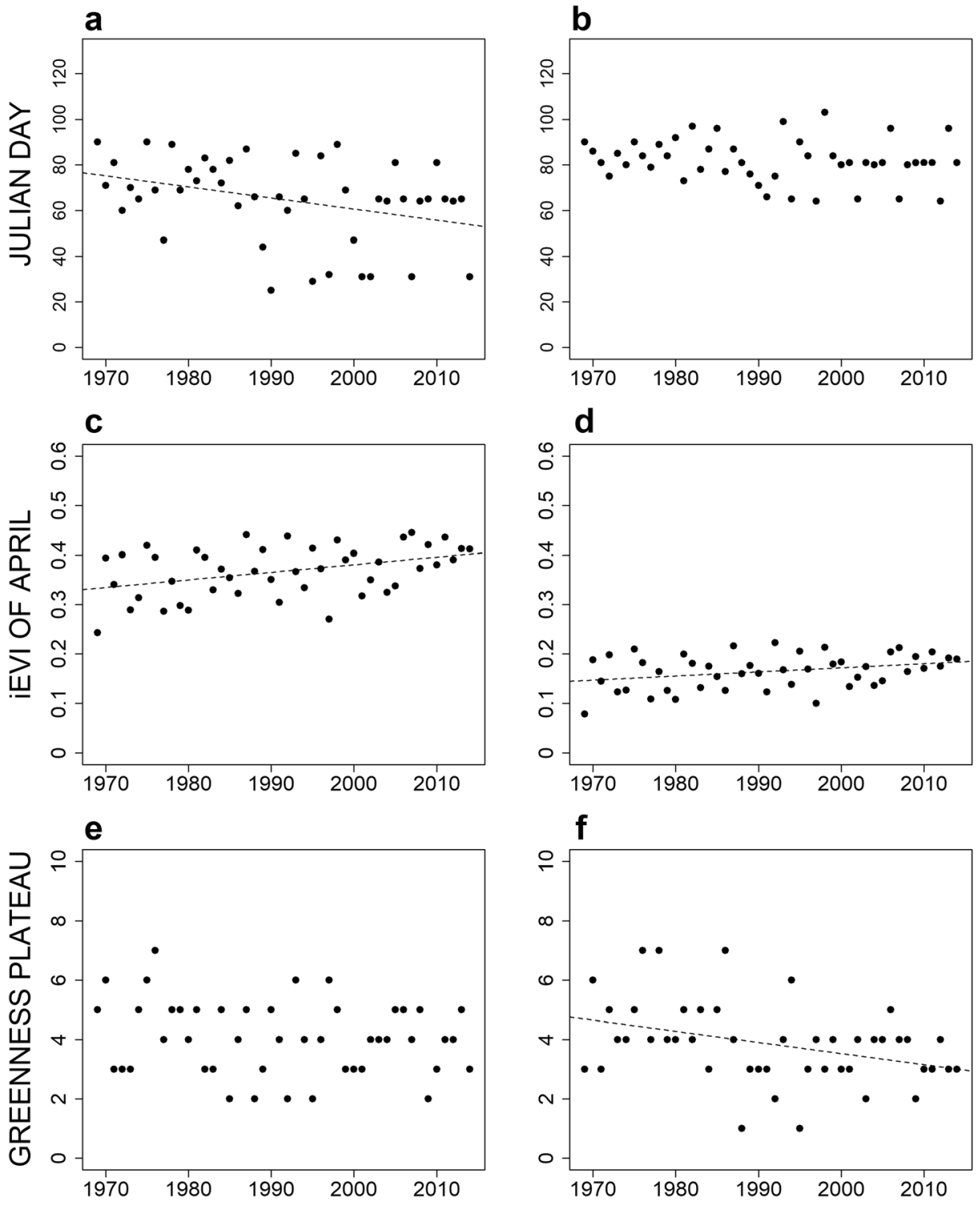

\section{YEAR}

Fig. 2 Changes in onset of green-up (as Julian days) through 1970-2014, in 1700-2000 m (a) and > $2000 \mathrm{~m}$ (b) Alpine grasslands. Changes in maximum rate of growth in early spring (iEVI of April) through 1970-2014, in 1700-2000 m (c) and > $2000 \mathrm{~m}$ (d) Alpine grasslands. Changes in duration of the greenness plateau (no. of days) through 1970-2014, in 1700-2000 m (e) and > $2000 \mathrm{~m}$ (f) Alpine grasslands. When, significant, a regression line has been added

and Fig. S5, Supplementary Material 1). In all scenarios, the yearling juvenile $_{t-1}$ ratio of chamois showed a decreasing trend over the years, from a median of c. $85 \%$ to $99 \%$ (Fig. 4a-d). Furthermore, the observed ratios (Fig. 4a-d, dots) fall within the variability intervals of simulated values for all the scenarios, which validates the predicted yearling $t_{t}$ juvenile ${ }_{t-1}$ ratios. 


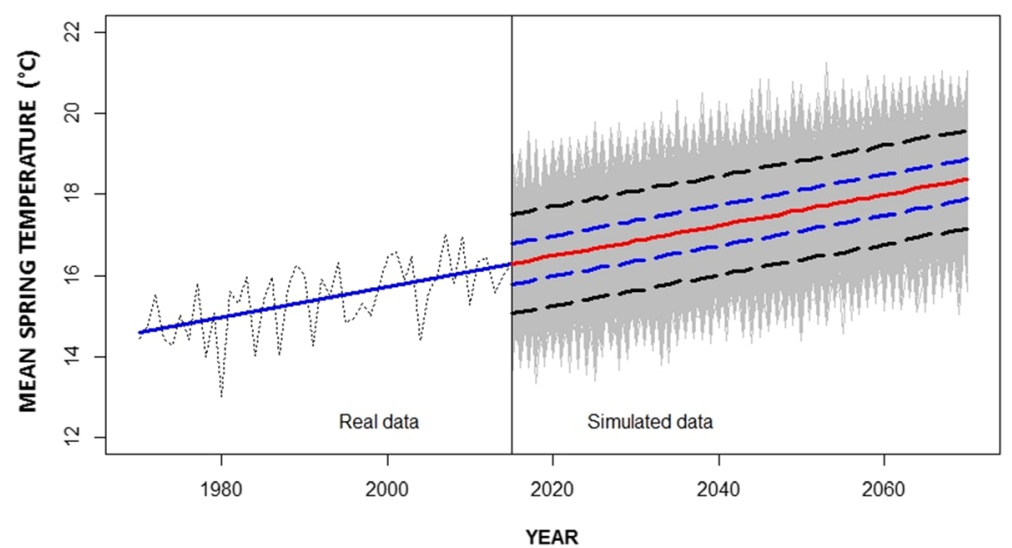

Fig. 3 1970-2014: observed mean spring temperatures (dotted line), with trend estimated by OSL regression (blue line). 2015-2070: simulated trajectories of mean spring temperature (grey area), with red line denoting the median of simulated temperature, at each year (blue dashed lines: 75th and 5th percentiles; black dashed lines: 25th and 95th percentiles)

For each scenario, the percentage of simulated trajectories reaching a yearling $t$ juvenile $_{\mathrm{t}-1}$ ratio equal to 0 are shown in Fig. 4e (see also Table S13, Supplementary Material 1, for raw values). All scenarios predicted a decreasing trend in yearling $\mathrm{t}_{\mathrm{t}}$ juvenile $_{\mathrm{t}-1}$ ratios, with an optimistic decrease of $c .28 \%$ (scenario $\mathrm{B}$, assuming a power relationship with negative exponent occurring between temperature and proportion of plots containing clover) to a pessimistic one of c. $95 \%$ (scenario $\mathrm{C}$, a power relationship with positive exponent) (Fig. 4e).

\section{Discussion}

Over the last five decades, in the Central Apennines, an increase of temperature $\left(2{ }^{\circ} \mathrm{C}\right)$ has anticipated the onset of green-up in montane grasslands $(c .1700-2000 \mathrm{~m})$ by nearly 1 month, but not at higher elevations (c. 2000-2200 m). Ungulates living on low mountain ranges, such as the Apennines, may be the first to experience the effects of the ongoing climatic changes on vegetation, because of the absence of upper elevations as potential refuge areas. Conversely, ungulates inhabiting higher mountains have the opportunity to shift their elevational range following the changing distribution of key-plant associations (Lenoir et al. 2008; Gottfried et al. 2012; Pauli et al. 2012; Telwala et al. 2013). Yet, in the Quaternary, few climate changes have lasted less than 200-300 years, with temperature oscillations between c. 1.5 and c. $20^{\circ} \mathrm{C}$ (Lourens 2004; Crawford 2014; Wanner et al. 2015), and there is no reason to expect that the ongoing one should be an exception. Even if its origin were solely human, the effects of the present load of greenhouse gases in the atmosphere would last at least 100 more years (Steffen et al. 2018). As to mountain ungulates, far greater effects than those which are detected presently will occur, also on high mountain ranges, especially in case of a further increase of temperature. For example, habitat losses due to climatic changes have been predicted for Nilgiri tahr Nilgiritragus hylocrius, Western Ghats, India (Sony et al. 2018), for Marco Polo argali Ovis ammon polii, in Tajikistan (Salas et al. 2018), and for other ungulate species in the Tibetan plateau (Schaller 2012; Luo et al. 2015; Jiang et al. 2020). 

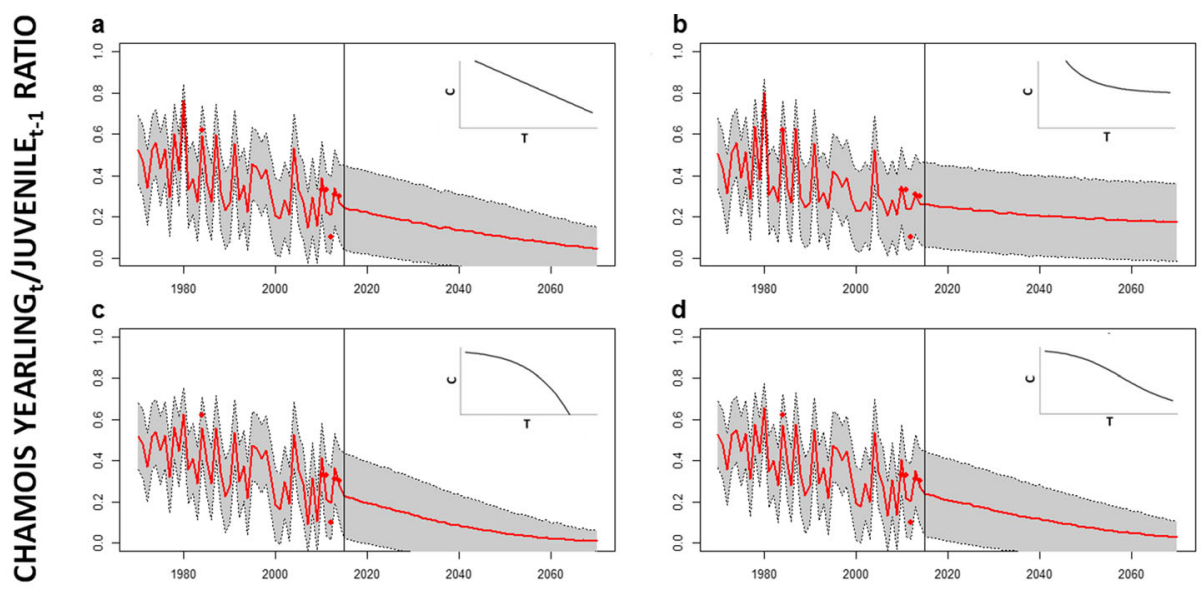

YEAR

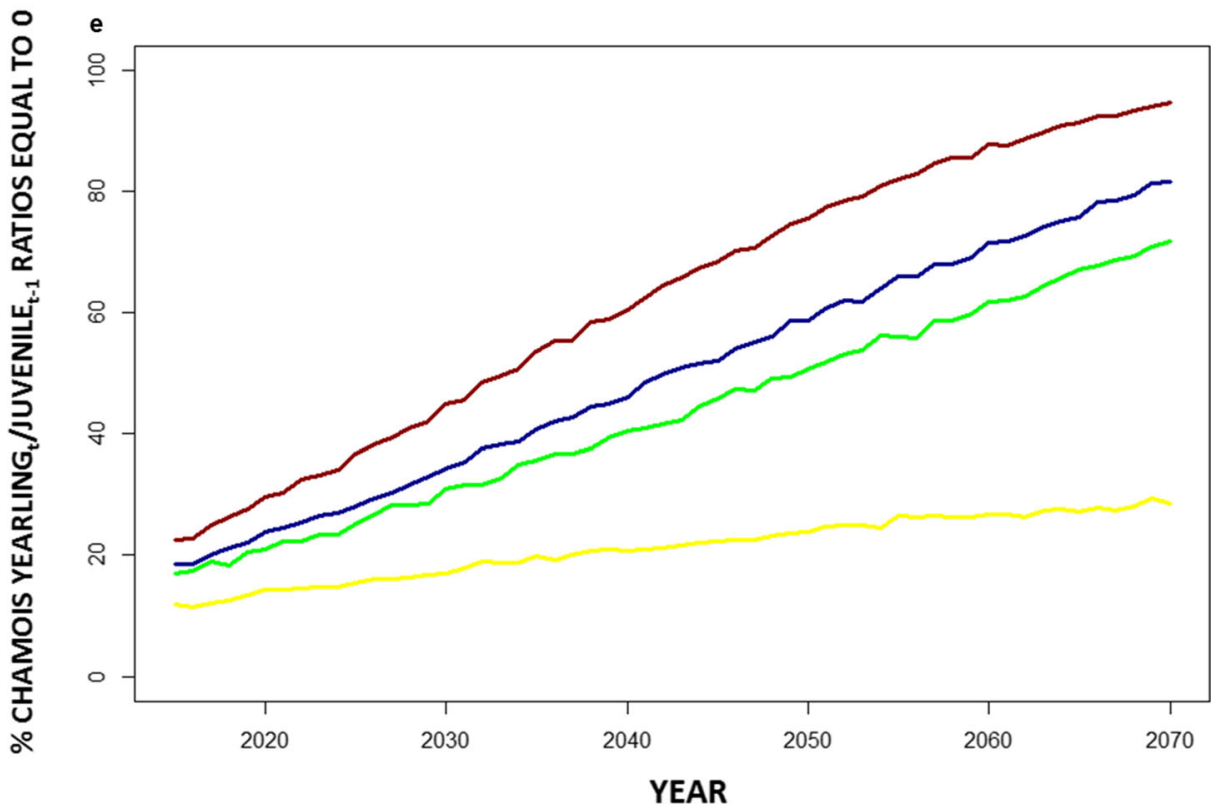

Fig. 4 a-d Simulated trajectories of yearling ${ }_{t} /$ juvenile $_{t-1}$ ratio of chamois (red line: average; grey area: standard deviation) obtained by trajectories of proportion of plots containing clover, through models depicting four scenarios (a linear; b positive power; c negative power; $\mathbf{d}$ sigmoidal; cf. Methods). Insets: assumed relationships between spring temperature and proportion of plots containing clover which underlie each scenario; T: mean spring temperature $\left({ }^{\circ} \mathrm{C}\right), \mathrm{C}$ : percentage of plots containing clover. e Percentages of simulated trajectories of chamois yearling /juvenile $_{t-1}$ ratio equal to 0 (i.e. juvenile winter mortality) in four different scenarios (A: green line; B: yellow line; C: red line; D: blue line), up to 2070

A mountain ungulate may survive the new conditions either by adapting through behavioural plasticity or by shifting its range to higher elevations. When neither compensatory mechanisms occur, the effect of increasing temperature could be detrimental. Behavioural adaptations have been suggested for the Alpine chamois $R$. rupicapra rupicapra, which increased both bite and step rates when foraging in less productive patches and at higher 
temperatures (Puorger et al. 2018). Conversely, the ibex Capra ibex shifts its foraging areas upslope to fulfil thermoregulatory requirements with increasing temperature, although with ensuing nutritional deficits (Mason et al. 2017). Likewise, Büntgen et al. (2017) reported that, in the last 22 years, Alpine chamois and especially ibex have increased the elevation of their ranges considerably, in the Central Alps (see also Brivio et al. 2019, for ibex). In the absence of compensatory processes, effects could be negative. Mason et al. (2014b) suggested that Alpine chamois will reduce the time spent foraging with the projected increase of temperatures in the next decades. Accordingly, a sharp decline in body mass of juvenile Alpine chamois has been recorded in the last 30 years, in an Alpine area-although a local increase of density could have been involved (Mason et al. 2014a). Mountain ungulates inhabiting low mountains, e.g. the Apennines (this paper) and the Nilgiri Ghats (Sony et al. 2018), and/or sub-arid massifs e.g. Al Hajar Mountains (Ross et al. 2019) and North-African massifs (DGF and UICN 2017), will be unable to shift their range upslope. Furthermore, even when mountain-dwelling ungulates can shift their ranges to higher elevations, the conical shape of mountains usually implies a lower availability of potentially suitable areas with increasing elevation (White et al. 2018; Brivio et al. 2019), although this pattern may vary with mountain topography (Elsen and Tingley 2015). Comparable effects of climatic changes, i.e. elevational range shift and/or habitat loss, have been also predicted for other mountain herbivores (American pika Ochotona princeps: Schwalm et al. 2016, Johnston et al. 2019; Royle's pika Ochotona roylei: Bhattacharyya et al. 2018; Alpine marmot Marmota marmota: Rézouki et al. 2016; mountain hare Lepus timidus: Rehnus et al. 2018) and, in turn, for cold-adapted predators (Arctic fox Vulpes lagopus: Tannerfeldt et al. 2002; snow leopard Panthera uncia: Aryal et al. 2016; Li et al. 2016). In fact, global effects of climatic changes have been suggested from invertebrates to endotherms (Harrington et al. 1999; Root et al. 2003).

Climate change will determine different responses in populations of mountain ungulates in relation to their specific ecological requirements. Nevertheless, one should expect not only range shifts — where possible — but also local decreases and extinctions. Our findings suggest that increasing spring temperatures will reduce the availability of snowbed vegetation (cf. Liberati et al. 2019), including the best food resources for Apennine chamois, in turn leading to negative demographic consequences. Juvenile mortality is one of the main factors influencing the demographic pattern of animal populations (Gaillard et al. 2000, for ungulates). Our most optimistic scenario has predicted that the yearling $\mathrm{j}_{t} \mathrm{juvenile}_{t-1}$ ratios equal to 0 (i.e. juvenile winter mortality) will increase to $c$. $28 \%$ by 2070 , while the most pessimistic one has predicted a local near-extinction (c. 95\% losses). The Apennine chamois does not seem to show compensatory adaptations (but see Puorger et al. 2018, for the Alpine chamois): its foraging efficiency has apparently decreased in "poor" areas (Ferretti et al. 2015) and with increasing temperature or decreasing rainfall (Ferretti et al. 2018). In turn, the negative consequences of warmer weather should be very important for mountain-dwelling ungulates living at relatively low elevations, as the Apennine chamois. Interspecific interactions can modify the impact of climate changes: ecologically flexible species may not be affected so much as specialised ones, with the former outcompeting the latter (fish: Van Zuiden et al. 2016; birds: Wittwer et al. 2015; mammals: Tannerfeldt et al. 2002). The use of grassland by red deer is an important factor accelerating the depletion of resources for chamois (Central Alps: Anderwald et al. 2015; Corlatti et al. 2019; Central Apennines: Lovari et al. 2014; Ferretti et al. 2015). The spread of unpalatable pioneer tall grass (for the Central Apennines: Malatesta et al. 2019) and the concurrent reduction of foraging areas (for our study area: Lovari et al. 2014; Corazza et al. 2016) may also play a role, helping the recolonisation of Alpine grasslands by woodland 
(Gehrig-Fasel et al. 2007; Espunyes et al. 2019). A warming temperature may also influence the life cycle of parasites, leading to a faster development rate, a longer period when a transmission is possible and increasing transmission rate (e.g. Kutz et al. 2005, 2009), further affecting individuals weakened by food depletion (Craig et al. 2008; Hughes et al. 2009). As to female Apennine chamois, pasture depletion has been associated with a reduction of feeding efficiency and diet quality (Ferretti et al. 2015), to an increase of intra-group feeding interference and endogenous response to stress (Fattorini et al. 2018), as well as to a reduced intensity/ frequency of suckling provided to juveniles (Scornavacca et al. 2016). Mountain ungulates must give birth at the beginning of the green-up period, as the mother's milk and the food resources on which the offspring will be weaned are more nutritious (e.g. Pettorelli et al. 2007). Our data show that, in an area of the Central Apennines, there has been a significant increase of spring temperatures, an anticipation by $c .25$ days in the onset of green-up, with no increase in the duration of the "greenness" plateau. Conversely, the timing of the chamois rut and births have not changed over the last few decades (1979-2014; Lovari 1984; Lovari and Locati 1991; S.L., personal observations), suggesting a decrease in temporal availability of nutritious pasture for chamois offspring and their mothers. A poor pasture will influence milk quality/ quantity as well as the availability of rich food resources for weaning juveniles, in turn reducing their body growth and increasing their winter mortality (e.g. Festa-Bianchet 1988; Coté and Festa-Bianchet 2001; Douhard et al. 2018), which is a crucial determinant of changes in population size of ungulates (Gaillard et al. 1998, 2000).

Not surprisingly, chamois numbers have been increasing in areas where they were recently reintroduced, as there they are still in the colonizing phase (sensu Caughley 1970), following release in suitable habitat (Mari and Lovari 2006). In most of the translocation areas, the occurrence of higher elevations ( $>2000 \mathrm{~m}$ ) could be an important factor promoting the future viability of chamois populations. For example, in Majella National Park, at higher elevations (2400-2790 m a.s.1.) than in our study area, $T$. thalii nutritious patches have been increasing in response to the milder temperatures of the last few decades (e.g. + c. 300\% abundance in grasslands, in 1972-2014; Evangelista et al. 2016), confirming our hypothesis of an upward shift of vegetation where higher elevations are available. In spite of their recent increase on mountains above $2000 \mathrm{~m}$, Apennine chamois have decreased by c. $20 \%$ in their original range from ALMNP (Latini et al. 2015b). The increase of numbers in translocated populations should not be taken as a sign of long-lasting recovery as - all other factors remaining equal - the negative effects of climate changes, presently impinging on chamois populations at lower elevations, should be expected to shift to the higher ones, in the future. Furthermore, red deer have been reintroduced to all areas of translocation of Apennine chamois and one should expect an increase in competition between deer and chamois. If we consider that few Quaternary climate changes have been shorter than 200-300 years and that the present one started less than 100 years ago (Crawford 2014), with a sharp increase in the last 50 years, effects at population level can be expected to be long-lasting and profound.

Global conclusions on absolute extinctions may not be drawn, as the effects of climate changes will vary with the ecological and behavioural flexibility of different species of mountain ungulates, geographical heterogeneity in mountain topography, topoclimatic effects shaping the availability of microrefugia, as well as with the arrival of ecologically competing species. However, shifts in distribution ranges and local decreases up to extinctions should be expected (Wiens 2016, for a review). This will require farsighted measures of adaptive management (e.g. avoiding the introduction of alien species and the human alteration of suitable habitats, as well as contrasting the arrival of potentially competing species; Ferretti and Lovari 2014) to help the conservation of mountain species of herbivores at risk. 
Acknowledgements We are indebted to the ALMNP officials (G. Rossi and D. Febbo) for their support. We thank C. Ferrari and M. Corazza for their comments on botanical issues, as well as L. Corlatti, M. Festa-Bianchet, J-M. Gaillard and A. Meriggi, for their suggestions. NOAA/OAR/ESRL PSD (Boulder, Colorado, USA) provided GHCN Gridded V2 data from their website at https://www.esrl.noaa.gov/psd. Two anonymous reviewers improved the manuscript.

Authors' contributions Conceptualization: SL, FF, LF, NF. Field work: SL, FF, NF. Remote-sensing analyses: GC. Statistics/simulations: SF, LF. Writing: SL, NF, LF, GC, SF, FF.

Funding information Open access funding provided by Università degli Studi di Siena within the CRUICARE Agreement. This research did not receive any specific grant from funding agencies in the public, commercial, or not-for-profit sectors.

\section{Compliance with ethical standards}

Conflicts of interest The authors declare that they have no conflict of interest.

Open Access This article is licensed under a Creative Commons Attribution 4.0 International License, which permits use, sharing, adaptation, distribution and reproduction in any medium or format, as long as you give appropriate credit to the original author(s) and the source, provide a link to the Creative Commons licence, and indicate if changes were made. The images or other third party material in this article are included in the article's Creative Commons licence, unless indicated otherwise in a credit line to the material. If material is not included in the article's Creative Commons licence and your intended use is not permitted by statutory regulation or exceeds the permitted use, you will need to obtain permission directly from the copyright holder. To view a copy of this licence, visit http://creativecommons.org/licenses/by/4.0/.

\section{References}

Anderwald P, Herfindal I, Haller RM, Risch AC, Schütz M, Schweiger AK, Filli F (2015) Influence of migratory ungulate management on competitive interactions with resident species in a protected area. Ecosphere 6:118

Aryal A, Shrestha UB, Ji W, Ale SB, Shrestha S, Ingty T, Maraseni T, Cockfield G, Raubenheimer D (2016) Predicting the distributions of predator (snow leopard) and prey (blue sheep) under climate change in the Himalaya. Ecol Evol 6:4065-4075

Asprea A (2016) Struttura e dinamica di popolazione del camoscio appenninico (Rupicapra pyrenaica ornata) nel Parco Nazionale d'Abruzzo, Lazio e Molise. Ente Parco Nazionale d'Abruzzo, Lazio, Molise. Available at: http://www.parcoabruzzo.it/pdf/Camoscio_Relazione_finale_2016.pdf

Ballesteros M, Bårdsen B-J, Fauchald P, Langeland K, Stien A, Tveera T (2013) Combined effects of long-term feeding, population density and vegetation green-up on reindeer demography. Ecosphere 4:1-13

Beniston M (1997) Variations of snow depth and duration in the Swiss Alps over the last 50 years: links to changes in large scale climatic forcings. Clim Chang 36:281-300

Beniston M, Farinotti D, Stoffel M, Andreassen LM, Coppola E, Eckert N et al (2018) The European mountain cryosphere: a review of its current state, trends, and future challenges. Cryosphere 12:759-794

Bhattacharyya S, Dawson DA, Hipperson H, Ishtiaq F (2018) A diet rich in C3 plants reveals the sensitivity of an alpine mammal to climate change. Mol Ecol 28:250-265

Braun-Blanquet J (1964) Pflanzensoziologie, $3^{\text {rd }}$ edn: New York: Springer

Brivio F, Zurmühl M, Grignolio S, von Hardenberg J, Apollonio M, Ciuti S (2019) Forecasting the response to global warming in a heat-sensitive species. Sci Rep 9:3048

Büntgen U, Greuter L, Bollmann K, Jenny H, Liebhold A, Galván JD, Stenseth NC, Carrie A, Mysterud A (2017) Elevational range shifts in four mountain ungulate species from the Swiss Alps. Ecosphere 8:e01761

Caughley G (1970) Eruption of ungulate populations, with emphasis on Himalayan thar in New Zealand. Ecology 51:53-72

Ciucci P, Tosoni E, Di Domenico G, Quattrociocchi F, Boitani L (2014) Seasonal and annual variation in the food habits of Apennine brown bears, central Italy. J Mammal 95:572-586 
Ciucci P, Mancinelli S, Boitani L, Gallo O, Grottoli L (2020) Anthropogenic food subsidies hinder the ecological role of wolves: insights for conservation of apex predators in human-modified landscapes. Glob Ecol Conserv 21:e00841

Corazza M, Tardella FM, Ferrari C, Catorci A (2016) Tall grass invasion after grassland abandonment influences the availability of palatable plants for wild herbivores: insight into the conservation of the Apennine chamois Rupicapra pyrenaica ornata. Environ Manag 57:1247-1261

Corlatti L, Gugiatti A, Ferrari N, Formenti N, Trogu T, Pedrotti L (2018) The cooler the better? Indirect effect of spring-summer temperature on fecundity in a capital breeder. Ecosphere 9:e02326

Corlatti L, Bonardi A, Bragalanti N, Pedrotti L (2019) Long-term dynamics of Alpine ungulates suggest interspecific competition. J Zool 309:241-249

Corlatti L, Herrero J, Ferretti F, Anderwald P, Garcì-Gonzalez R, Hammer S, Nores C, Rossi L, Lovari S (in press) Chamois, Rupicapra rupicapra (Linnaeus, 1758) and Rupicapra pyrenaica (Bonaparte, 1845). In: Zachos F, Corlatti L (eds) Handbook of the mammals of Europe - terrestrial Cetartiodactyla. Springer Nature

Coté SD, Festa-Bianchet M (2001) Birthdate, mass and survival in mountain goat kids: effects of maternal characteristics and forage quality. Oecologia 127:230-238

Cowpertwait PSP, Metcalfe AV (2009) Introductory time series with R. Springer-Verlag, New York

Craig BH, Tempest LJ, Pilkington JG, Pemberton JM (2008) Metazoan-protozoan parasite co-infections and host body weight in St Kilda Soay sheep. Parasitology 135:433-441

Crawford RM (2014) Tundra-taiga biology. Oxford University Press, New York

DGF et UICN (2017) Stratégie et plan d'action pour la conservation du mouflon à manchettes (Ammotragus lervia) en Tunisie 2018-2027. UICN/DGF, Malaga

Dobrowski SZ (2011) A climatic basis for microrefugia: the influence of terrain on climate. Glob Chang Biol 17: $1022-1035$

Douhard M, Guillemette S, Festa-Bianchet M, Pelletier F (2018) Drivers and demographic consequences of seasonal mass changes in an alpine ungulate. Ecology 99:724-734

Duprè E, Monaco A, Pedrotti L (2001) Piano d'Azione Nazionale per il camoscio appenninico Rupicapra pyrenaica ornata. Quaderni di Conservazione della Natura 10. Ministero dell'Ambiente e della Tutela del Territorio, Istituto Nazionale per la Fauna Selvatica “Alessandro Ghigi”. Available at: http://www. isprambiente.gov.it/files/pubblicazioni/quaderni/conservazione-natura/files/6715_10_qcn_camoscio.pdf

Elsen PR, Tingley MW (2015) Global mountain topography and the fate of montane species under climate change. Nat Clim Chang 5:772-776

Espunyes J, Lurgi M, Büntgen U, Bartolomé J, Calleja JA, Gálvez-Cerón A, Penuelas J, Serrano E (2019) Different effects of alpine woody plant expansion on domestic and wild ungulates. Glob Chang Biol 25: 1808-1819

Evangelista A, Frate L, Carranza ML, Attorre F, Pelino G, Stanisci A (2016) Changes in composition, ecology and structure of high-mountain vegetation: a re-visitation study over 42 years. AoB Plants 8:plw004

Fabbri M, Boscagli G, Lovari S (1983) The brown bear population of Abruzzo. Acta Zool Fenn 174:163-164

Fattorini N, Brunetti C, Baruzzi C, Macchi E, Pagliarella MC, Pallari N, Lovari S, Ferretti F (2018) Being "hangry": food depletion and its cascading effects on social behaviour. Biol J Linn Soc 125:640-656

Fattorini N, Brunetti C, Baruzzi C, Chiatante GP, Lovari S, Ferretti F (2019) Temporal variation of foraging activity and grouping patterns in a mountain-dwelling herbivore: environmental and endogenous drivers. Behav Process 167:103909

Ferrari S, Cribari-Neto F (2004) Beta regression for modeling rates and proportions. J Appl Stat 31:799-815

Ferrari C, Rossi G (1995) Relationships between plant communities and late snow melting on Mount Prado (northern Apennines, Italy). Vegetatio 120:49-58

Ferrari C, Rossi G, Cavani C (1988) Summer food habits and quality of female, kid and subadult Apennine chamois, Rupicapra pyrenaica ornata Neumann, 1899 (Artiodactyla, Bovidae). Z Säugetierkd 53:170-177

Ferretti F, Lovari S (2014) Introducing aliens: problems associated with invasive exotics. In: Putman RJ, Apollonio M (eds) Behaviour and management of European ungulates. Whittles Publishing, Dunbeath, pp 78-109

Ferretti F, Corazza M, Campana I, Pietrocini V, Brunetti C, Scornavacca D, Lovari S (2015) Competition between wild herbivores: reintroduced red deer and Apennine chamois. Behav Ecol 26:550-559

Ferretti F, Lovari S, Stephens PA (2018) Joint effects of weather and interspecific competition on foraging behaviour and survival of a mountain herbivore. Curr Zool 65:165-175

Festa-Bianchet M (1988) Birthdate and survival in bighorn lambs (Ovis canadensis). J Zool 214:653-661

Festa-Bianchet M, Jorgenson JT (1998) Selfish mothers: reproductive expenditure and resource availability in bighorn ewes. Behav Ecol 9:144-150

Gaillard JM, Festa-Bianchet M, Yoccoz NG (1998) Population dynamics of large herbivores: variable recruitment with constant adult survival. Trends Ecol Evol 13:58-63 
Gaillard JM, Festa-Bianchet M, Yoccoz NG, Loison A, Toïgo C (2000) Temporal variation in fitness components and population dynamics of large herbivores. Annu Rev Ecol Evol Syst 31:367-393

Garel M, Gaillard J-M, Jullien J-M, Dubray D, Maillard D, Loison A (2011) Population abundance and early spring conditions determine variation in body mass of juvenile chamois. J Mammal 92:1112-1117

Gavin DG, Fitzpatrick MC, Gugger PF, Heath KD, Rodríguez-Sánchez F, Dobrowski SZ et al (2014) Climate refugia: joint inference from fossil records, species distribution models and phylogeography. New Phytol 204:37-54

Gehrig-Fasel J, Antoine G, Zimmermann NE (2007) Tree line shifts in the Swiss Alps: climate change or land abandonment? J Veg Sci 18:571-582

Gottfried M, Pauli H, Futschik A, Akhalkatsi M, Barančok P, Alonso JLB et al (2012) Continent-wide response of mountain vegetation to climate change. Nat Clim Chang 2:111-115

Hamel S, Garel M, Festa-Bianchet M, Gaillard J-M, Côté SD (2009) Spring Normalized Difference Vegetation Index (NDVI) predicts annual variation in timing of peak faecal crude protein in mountain ungulates. $\mathrm{J}$ Appl Ecol 46:582-589

Harrington R, Woiwod I, Sparks T (1999) Climate change and trophic interactions. Trends Ecol Evol 14:146150

Hegerl GC, Brönnimann S, Schurer A, Cowan T (2018) The early 20th century warming: anomalies, causes, and consequences. Wires Clim Chang 9:e522

Hersteinsson P, Macdonald DW (1992) Interspecific competition and the geographical distribution of red and arctic foxes Vulpes vulpes and Alopex lagopus. Oikos 64:505-515

Hewitt G (1996) Some genetic consequences of ice ages, and their role in divergence and speciation. Biol J Linn Soc 58:247-276

Huete A, Didan K, Miura T, Rodriguez EP, Gao X, Ferreira LG (2002) Overview of the radiometric and biophysical performance of the MODIS vegetation indices. Remote Sens Environ 83:195-213

Hughes J, Albon SD, Irvine RJ, Woodin S (2009) Is there a cost of parasites to caribou? Parasitology 136:253265

Jiang F, Zhang J, Gao H, Cai Z, Zhou X, Li S, Zhang T (2020) Musk deer (Moschus spp.) face redistribution to higher elevations and latitudes under climate change in China. Sci Total Environ 704:135335

Johnson NL, Kotz S (1970) Continuous univariate distributions Vol. 2. Wiley, New York

Johnston AN, Bruggeman JE, Beers A, Beever EA, Christophersen R, Ransom JI (2019) Ecological consequences of anomalies in atmospheric moisture and snowpack. Ecology:e02638

Justice CO, Townshend JRG, Vermote EF, Masuoka E, Wolfe RE, Saleous N, Roy DP, Morisette JT (2002) An overview of MODIS land data processing and product status. Remote Sens Environ 83:3-15

Kalnay E, Kanamitsu M, Kistler R, Collins W, Deaven D, Gandin L et al (1996) The NCEP/NCAR 40-year reanalysis project. Bull Am Meteorol Soc 77:437-471

Kaskaoutis DG, Houssos EE, Goto D, Bartzokas A, Nastos PT, Sinha PR et al (2014) Synoptic weather conditions and aerosol episodes over Indo-Gangetic Plains, India. Clim Dynam 43:2313-2331

Kemp MU, van Loon EE, Shamoun-Baranes J, Bouten W (2012) RNCEP: global weather and climate data at your fingertips. Methods Ecol Evol 3:65-70

Kutz SJ, Hoberg EP, Polley L, Jenkins EJ (2005) Global warming is changing the dynamics of Arctic hostparasite systems. Proc R Soc B Biol Sci 272:2571-2576

Kutz SJ, Jenkins EJ, Veitch AM, Ducrocq J, Polley L, Elkin B, Lair S (2009) The Arctic as a model for anticipating, preventing, and mitigating climate change impacts on host-parasite interactions. Vet Parasitol $163: 217-228$

Latini R, Asprea A (2014) Conteggi in simultanea della popolazione di camoscio appenninico nel PNALM: nota sintetica dei risultati autunno 2014. Ente Parco Nazionale d'Abruzzo, Lazio, Molise. Available at: http:/www.parcoabruzzo.it/pdf/Relazione_Conteggio_camosci_autunno_2014PNALM.pdf

Latini R, Asprea A, Pagliaroli D, Gentile L, Argenio A, Di Pirro V (2013) Life+ Coornata. Development of coordinated protection measures for Apennine chamois (Rupicapra pyrenaica ornata). Stato dell'arte delle azioni C2 e C6. Available at: http://www.parcoabruzzo.it/pdf/Relazione_conteggio_camoscio_finale_2012. pdf

Latini R, Asprea A, Pagliaroli D (2015a) Stima della densità della popolazione di cervo e di capriolo nel Parco Nazionale d'Abruzzo, Lazio e Molise. Ente Parco Nazionale d'Abruzzo, Lazio, Molise. Available at: http://www.parcoabruzzo.it/Pdf/progetti/PNALMpro155-1.pdf

Latini R, Asprea A, Pagliaroli D, Argenio A, Di Pirro V, Gentile V (2015b) Potential threats to the historical autochtonous Apennine chamois population in Abruzzo, Lazio e Molise National Park: analysis, valuation and management implications. In: Antonucci A, Di Domenico G. (eds) Chamois International Congress Proceedings. 17-19 June 2014, Lama dei Peligni, Majella National Park, Italy. Majambiente Edizioni, Chieti, pp $41-46$

Legendre P, Legendre L (1998) Numerical ecology. Elsevier, Amsterdam 
Lenoir J, Gégout JC, Marquet PA, De Ruffray P, Brisse H (2008) A significant upward shift in plant species optimum elevation during the $20^{\text {th }}$ century. Science $320: 1768-1771$

Li J, McCarthy TM, Wang H, Weckworth BV, Schaller GB, Mishra C, Lu Z, Beissinger SR (2016) Climate refugia of snow leopards in High Asia. Biol Conserv 203:188-196

Liberati L, Messerli S, Matteodo M, Vittoz P (2019) Contrasting impacts of climate change on the vegetation of windy ridges and snowbeds in the Swiss Alps. Alpine Bot 129:95-105

Loison A, Jullien JM, Menaut P (1999) Relationship between chamois and isard survival and variation in global and local climate regimes: contrasting examples from the Alps and Pyrenees. Ecol Bull 47:126-136

Lorenzini R, Lovari S (2006) Genetic diversity and phylogeography of the European roe deer: the refuge area theory revisited. Biol J Linn Soc 88:85-100

Lourens LJ (2004) Revised tuning of Ocean Drilling Program Site 964 and KC01B (Mediterranean) and implications for the $\delta 18 \mathrm{O}$, tephra, calcareous nannofossil, and geomagnetic reversal chronologies of the past 1.1 Myr. Paleoceanography 19:PA3010

Lovari S (1977) The Abruzzo chamois. Oryx 14:47-50

Lovari S (1984) Herding strategies of male Abruzzo chamois on the rut. Acta Zool Fenn 172:91-92

Lovari S (1985) Behavioural repertoire of the Abruzzo chamois, Rupicapra pyrenaica ornata Neumann, 1899 (Artiodactyla: Bovidae). Säugetierkundliche Mitteilungen 32:113-116

Lovari S, Cosentino R (1986) Seasonal habitat selection and group size of the Abruzzo chamois (Rupicapra pyrenaica ornata). Ital J Zool 53:73-78

Lovari S, Locati M (1991) Temporal relationships, transitions and structure of the behavioural repertoire in male Apennine chamois during the rut. Behaviour 119:77-103

Lovari S, Ventimiglia M, Minder I (2013) Food habits of two leopard species, competition, climate change and upper treeline: a way to the decrease of an endangered species? Ethol Ecol Evol 25:305-318

Lovari S, Ferretti F, Corazza M, Minder I, Troiani N, Ferrari C, Saddi A (2014) Unexpected consequences of reintroductions: competition between reintroduced red deer and Apennine chamois. Anim Conserv 17:359370

Luo Z, Jiang Z, Tang S (2015) Impacts of climate change on distributions and diversity of ungulates on the Tibetan Plateau. Ecol Appl 25:24-38

Malatesta L, Tardella FM, Tavoloni M, Postiglione N, Piermarteri K, Catorci A (2019) Land use change in the high mountain belts of the central Apennines led to marked changes of the grassland mosaic. Appl Veg Sci 22:243-255

Mari F, Lovari S (2006) Il camoscio appenninico: un ritorno in corso. In: Fraissinet M, Pedretti F (eds) Salvati dall'arca. Alberto Perdisa Editore, Bologna, pp 131-142

Martin E, Brun E, Durand Y (1994) Sensitivity of the French Alps snow cover to the variation of climatic variables. Ann Geophys 12:469-477

Masini F, Lovari S (1988) Systematics, phylogenetic relationships, and dispersal of the chamois (Rupicapra spp.). Quat Res 30:339-349

Mason TH, Apollonio M, Chirichella R, Willis SG, Stephens PA (2014a) Environmental change and long-term body mass declines in an alpine mammal. Front Zool 11:69

Mason TH, Stephens PA, Apollonio M, Willis SG (2014b) Predicting potential responses to future climate in an alpine ungulate: interspecific interactions exceed climate effects. Glob Chang Biol 20:3872-3882

Mason TH, Brivio F, Stephens PA, Apollonio M, Grignolio S (2017) The behavioral trade-off between thermoregulation and foraging in a heat-sensitive species. Behav Ecol 28:908-918

Morelli TL, Daly C, Dobrowski SZ, Dulen DM, Ebersole JL, Jackson ST et al (2016) Managing climate change refugia for climate adaptation. PLoS One 11:e0159909

Nogués-Bravo D, Araújo MB, Errea MP, Martinez-Rica JP (2007) Exposure of global mountain systems to climate warming during the $21^{\text {st }}$ century. Glob Environ Chang 17:420-428

Panuccio M, Barboutis C, Chiatante G, Evangelidis A, Agostini N (2016) Pushed by increasing air temperature and tailwind speed: weather selectivity of raptors migrating across the Aegean Sea. Ornis Fennica 93:159171

Parmesan C (2006) Ecological and evolutionary responses to recent climate change. Ann Rev Ecol Evol Syst 37 : 637-669

Parmesan C, Matthews J (2006) Biological impacts of climate change. In: Groom MJ, Meffe GK, Carroll R (eds) Principles of conservation biology. Sinhauer Associates Inc, Sunderland, pp333-360

Patalano M, Lovari S (1993) Food habits and trophic niche overlap of the wolf Canis lupus (L. 1758) and the red fox Vulpes vulpes (L. 1758) in a Mediterranean mountain area. Rev Ecol Terre Vie 48:279-294

Pauli H, Gottfried M, Dullinger S, Abdaladze O, Akhalkatsi M, Alonso JLB et al (2012) Recent plant diversity changes on Europe's mountain summits. Science 336:353-355

Perco F, Tassi F, Lovari S (1976) Das Gamswild von Abruzzen: gegenwaertige Lage und Forschungen. II Internationales Gamswild-Treffen Bled; 1976 Oct 21-23. Biotehniska Fakulteta, Ljubljana, pp 20-27 
Pettorelli N, Vik JO, Mysterud A, Gaillard J-M, Tucker CJ, Stenseth NC (2005) Using the satellite-derived NDVI to assess ecological responses to environmental change. Trends Ecol Evol 20:503-510

Pettorelli N, Pelletier F, von Hardenberg A, Festa-Bianchet M, Côté SD (2007) Early onset of vegetation growth vs. rapid green-up: impacts on juvenile mountain ungulates. Ecology 88:381-390

Pignatti S (1982) Flora d'Italia. Edagricole, Bologna

Primi R, Filibeck G, Amici A, Bückle C, Cancellieri L, Di Filippo A, Gentile C, Guglielmino A, Latini R, Mancini LD, Mensing SA, Rossi CM, Rossini F, Scoppola A, Sulli C, Venanzi R, Ronchi B, Piovesan G (2016) From Landsat to leafhoppers: A multidisciplinary approach for sustainable stocking assessment and ecological monitoring in mountain grasslands. Agric Ecosyst Environ 234:118-133

Puorger A, Rossi C, Haller RM, Anderwald P (2018) Plastic adaptations of foraging strategies to variation in forage quality in Alpine chamois (Rupicapra rupicapra). Can J Zool 96:269-275

Ravazzi C, Aceti A (2004) The timberline and treeline ecocline altitude during the Holocene Climatic Optimum in the Italian Alps and the Apennines. In: Antonioli F, Vai GB (eds) Climex Maps Italy. Explanatory notes. Proceedings of the 32nd International Geological Congress, Florence, Italy. Bologna, pp 21-22

Rehnus M, Bollmann K, Schmatz DR, Hackländer K, Braunisch V (2018) Alpine glacial relict species losing out to climate change: the case of the fragmented mountain hare population (Lepus timidus) in the Alps. Glob Chang Biol 24:3236-3253

Rézouki C, Tafani M, Cohas A, Loison A, Gaillard J-M, Allainé D, Bonenfant C (2016) Socially mediated effects of climate change decrease survival of hibernating Alpine marmots. J Anim Ecol 85:761-773

Rogora M, Frate L, Carranza ML, Freppaz M, Stanisci A, Bertani I et al (2018) Assessment of climate change effects on mountain ecosystems through a cross-site analysis in the Alps and Apennines. Sci Total Environ 624:1429-1442

Root TL, Price JT, Hall KR, Schneider SH, Rosenzweig C, Pounds JA (2003) Fingerprints of global warming on wild animals and plants. Nature 421:57-60

Ross S, Al-Rawahi H, Al-Jahdhami MH, Spalton JA, Mallon D, Al-Shukali AS, Al-Rasbi A, Al-Fazari W, Chreiki MK (2019) Arabitragus jayakari (errata version published in 2019) The IUCN Red List of Threatened Species 2019: e.T9918A156925170. https://doi.org/10.2305/IUCN.UK.2019-1.RLTS.T9918 A156925170.en. Downloaded on 24 June 2020

Rossi G (1985) Osservazioni sull'alimentazione del camoscio appenninico (Rupicapra pyrenaica ornata). Primo contributo. MSc Thesis, Università di Bologna

Rughetti M, Festa-Bianchet M (2012) Effects of spring-summer temperature on body mass of chamois. J Mammal 93:1301-1307

Running SW, Nemani RR, Heinsch FA, Zhao M, Reeves M, Hashimoto H (2004) A continuous satellite-derived measure of global terrestrial primary production. Bioscience 54:547-560

Salas EAL, Valdez R, Michel S, Boykin KG (2018) Habitat assessment of Marco polo sheep (Ovis ammon polii) in eastern Tajikistan: modeling the effects of climate change. Ecol Evol 8:5124-5138

Schaller GB (2012) Tibet wild. A naturalist's journeys on the roof of the world. Island Press, Washington, Covelo and London

Schröder W (1985) Management of mountain ungulates. In: Lovari S (ed) The biology and management of mountain ungulates. Cromm Helm, London and Sydney, pp 197-203

Schwalm D, Epps CW, Rodhouse TJ, Monahan WB, Castillo JA, Ray C, Jeffress MR (2016) Habitat availability and gene flow influence diverging local population trajectories under scenarios of climate change: a placebased approach. Glob Chang Biol 22:1572-1584

Scornavacca D, Brunetti C (2015) Cooperative defence of female chamois successfully deters an eagle attack. Mammalia 80:453-456

Scornavacca D, Lovari S, Cotza A, Bernardini S, Brunetti C, Pietrocini V, Ferretti F (2016) Pasture quality affects juvenile survival through reduced maternal care in a mountain-dwelling ungulate. Ethology 122:807817

Şekercioğlu ÇH, Primack RB, Wormworth J (2012) The effects of climate change on tropical birds. Biol Conserv 148:1-18

Shackleton DM (1997) Objectives, format and limitations of the Caprinae survey and action plan. In: Shackleton DM (ed) Wild sheep and goats and their relatives. IUCN Gland, Swizterland and Cambridge, pp 1-4

Sony RK, Sen S, Kumar S, Sen M, Jayahari KM (2018) Niche models inform the effects of climate change on the endangered Nilgiri Tahr (Nilgiritragus hylocrius) populations in the southern Western Ghats, India. Ecol Eng 120:355-363

Steffen W, Rockström J, Richardson K, Lenton TM, Folke C, Liverman D et al (2018) Trajectories of the earth system in the Anthropocene. P Nat Acad Sci 115:8252-8259

Stenseth NC, Durant JM, Fowler MS, Matthysen E, Adriaensen F, Jonzén N et al (2015) Testing for effects of climate change on competitive relationships and coexistence between two bird species. P Roy Soc B - Biol Sci 282:20141958 
Tannerfeldt M, Elmhagen B, Angerbjörn A (2002) Exclusion by interference competition? The relationship between red and arctic foxes. Oecologia 132:213-220

Telwala Y, Brook BW, Manish K, Pandit MK (2013) Climate-induced elevational range shifts and increase in plant species richness in a Himalayan biodiversity epicentre. PLoS One 8:e57103

Van Zuiden TM, Chen MM, Stefanoff S, Lopez L, Sharma S (2016) Projected impacts of climate change on three freshwater fishes and potential novel competitive interactions. Divers Distrib 22:603-614

Villamuelas M, Fernández N, Albanell E, Gálvez-Cerón A, Bartolomé J, Mentaberre G et al (2016) The enhanced vegetation index (EVI) as a proxy for diet quality and composition in a mountain ungulate. Ecol Indic 61:658-666

Wang MCK, Carter RL (1983) One-way analysis of variance with time-series data. Biometrics 39:747-751

Wanner H, Mercolli L, Grosjean M, Ritz SP (2015) Holocene climate variability and change; a data-based review. J Geol Soc Lond 172:254-263

White KS, Gregovich DP, Levi T (2018) Projecting the future of an alpine ungulate under climate change scenarios. Glob Chang Biol 24:1136-1149

Wiens JJ (2016) Climate-related local extinctions are already widespread among plant and animal species. PLoS Biol 14:e2001104

Wittwer T, O'hara RB, Caplat P, Hickler T, Smith HG (2015) Long-term population dynamics of a migrant bird suggests interaction of climate change and competition with resident species. Oikos 124:1151-1159

Zuur AF, Ieno EN, Smith GM (2007) Analysing ecological data. Springer, New York

Publisher's note Springer Nature remains neutral with regard to jurisdictional claims in published maps and institutional affiliations.

\section{Affiliations}

\section{Sandro Lovari ${ }^{1,2} \cdot$ Sara Franceschi ${ }^{3} \cdot$ Gianpasquale Chiatante $^{4} \cdot$ Lorenzo Fattorini $^{3}$. Niccolò Fattorini ${ }^{1} \cdot$ Francesco Ferretti $^{1}$}

1 Research Unit of Behavioural Ecology, Ethology and Wildlife Management, Department of Life Sciences, University of Siena, Via P.A. Mattioli 4, 53100 Siena, Italy

2 Maremma Natural History Museum, Strada Corsini 5, 58100 Grosseto, Italy

3 Department of Economics and Statistics, University of Siena, Piazza San Francesco 8, 53100 Siena, Italy

4 Department of Earth and Environmental Sciences, University of Pavia, Via Ferrata 1, 27100 Pavia, Italy 